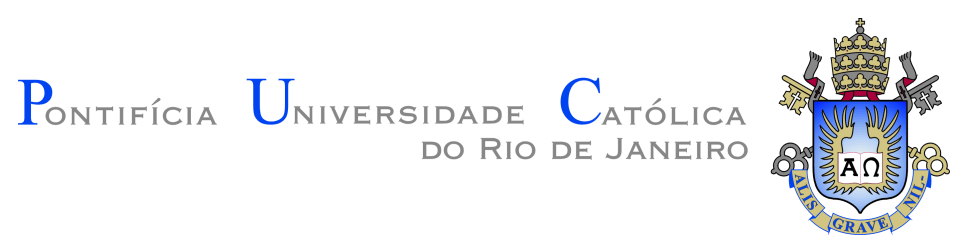

Eduardo Fagundes de Carvalho

School Time and Crime: Incapacitation Effects in Brazil

Dissertação de Mestrado

Thesis presented to the Programa de Pós-graduação em Economia da PUC-Rio in partial fulfillment of the requirements for the degree of Mestre em Economia.

Advisor: Prof. Claudio Abramovay Ferraz do Amaral 


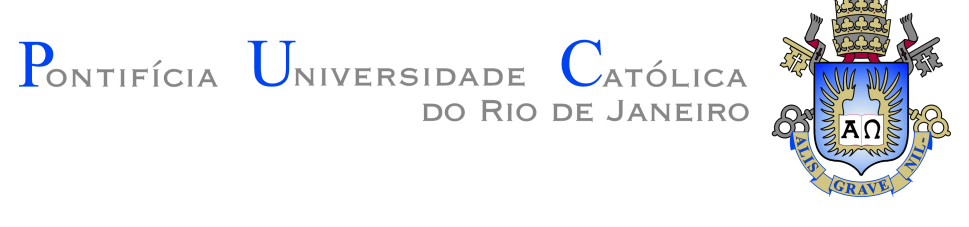

Eduardo Fagundes de Carvalho

\section{School Time and Crime: Incapacitation Effects in Brazil}

Thesis presented to the Programa de Pós-graduação em Economia da PUC-Rio in partial fulfillment of the requirements for the degree of Mestre em Economia. Approved by the Examination Committee.

Prof. Claudio Abramovay Ferraz do Amaral

Advisor

Departamento de Economia - PUC-Rio

Prof. Gustavo Gonzaga

Departamento de Economia - PUC-Rio

Dr. Daniel Cerqueira

Instituto de Pesquisa Econômica Aplicada - IPEA 
All rights reserved.

\section{Eduardo Fagundes de Carvalho}

B.A. in Economics, Pontifícia Universidade Católica do Rio de Janeiro (PUC-RIO), 2015.

Bibliographic data

Fagundes de Carvalho, Eduardo

School Time and Crime: Incapacitation Effects in Brazil / Eduardo Fagundes de Carvalho; advisor: Claudio Abramovay Ferraz do Amaral. - Rio de janeiro: PUC-Rio, Departamento de Economia, 2019.

v., 44 f: il. color. ; $30 \mathrm{~cm}$

Dissertação (mestrado) - Pontifícia Universidade Católica do Rio de Janeiro, Departamento de Economia.

Inclui bibliografia

1. Economia - Teses. 2. Desenvolvimento Econômico Teses. 3. Crime; . 4. Crime na Adolescência;. 5. Aumento no Tempo na Escola;. 6. Efeitos de Incapacitação;. 7. Programa Mais Educação;. 8. Dados georreferenciados.. I. Ferraz do Amaral, Claudio Abramovay. II. Pontifícia Universidade Católica do Rio de Janeiro. Departamento de Economia. III. Título. 


\section{Acknowledgments}

First, I would like to thank my advisor Claudio Ferraz for helping me grow as a researcher while patiently guiding me through the conclusion of this dissertation.

I also thank the professors and employees of the Department of Economics at PUC for providing a rich learning environment.

I thank my lifelong friends for always being there in the great and the not so great moments of my life.

I thank the colleagues and friends made at PUC with whom I am proud to have shared the past two years. In particular, thank you Cate and Bia for the positive peer effects and the amazing support in the thoughest times.

I thank my family, Carlos, Elke and João for the love and caring support throughout my life. I would not have made it this far without you.

Needless to say, thank you Barbara, for everything. I could repeat every single word stated above and it would not be enough to say how much I am thankful to have had you by my side for all these years.

Financial suppport from CAPES is gratefully acknowledged. This study was financed in part by the Coordenação de Aperfeiçoamento de Pessoal de Nível Superior - Brasil (CAPES) - Finance Code 001. Finally, I thank the generous people at Instituto Sou da Paz, Ministério do Desenvolvimento Social (MDS) and Fundo Nacional da Educação (FNDE) who have helped me throughout this research. 


\section{Abstract}

Fagundes de Carvalho, Eduardo; Ferraz do Amaral, Claudio Abramovay (Advisor). School Time and Crime: Incapacitation Effects in Brazil. Rio de Janeiro, 2019. 44p. Dissertação de mestrado - Departamento de Economia, Pontifícia Universidade Católica do Rio de Janeiro.

Juvenile crime imposes non-trivial costs to societies, which have made its determinants and deterrents increasingly subject of study by economists. School-based interventions are often proposed in order to mitigate the rise in criminal careers and the perpetuation of violence. However, the directions and channels through which schooling may affect crime vary. This paper studies one of them - namely the incapacitation effects - exploiting a federal program that extended school hours in Brazilian public schools. Using quasiexperimental variation in the probability of receiving the program and georeferenced crime data from the state of São Paulo, it is possible to estimate the causal effect of the program on criminal activity in the surroundings of the schools. Results suggest incapacitation does prevent juvelines from engaging in less offensive crimes, with stronger evidence for drug-related crimes and for schools with poorer students.

\section{Keywords}

Crime; Juvenile Crime; School Time Extension; Incapacitation Effects; Mais Educação Program; Georeferenced data. 


\section{Resumo}

Fagundes de Carvalho, Eduardo; Ferraz do Amaral, Claudio Abramovay. Tempo na Escola e Crime: Efeitos de Incapacitação no Brasil. Rio de Janeiro, 2019. 44p. Dissertação de Mestrado Departamento de Economia, Pontifícia Universidade Católica do Rio de Janeiro.

Crimes na adolescência impõem custos não triviais para a sociedade, o que tornou seus determinantes e fatores dissuasivos cada vez mais sujeitos a estudo por economistas. Intervenções no nível da escola são comumente propostas com o objetivo de mitigar o surgimento de carreiras criminais e a perpetuação da violência. Entretanto, as direções e os canais pelos quais as escolas afetam crime podem variar. Esse artigo estuda um deles - os esfeitos de incapacitação - explorando um programa federal que aumentou as horas escolares em escolas públicas brasileiras. Usando variação quasiexperimental na probabilidade de aderir ao programa e dados georreferenciados de crime do estado de São Paulo, é possível estimar os feitos causais do programa em atividade criminal ao redor das escolas. Os resultados sugerem que incapacitação de fato previne jovens de cometerem crimes menos severos, com evidência mais forte para crimes relacionados a drogas e para escolas com alunos mais pobres.

\section{Palavras-chave}

Crime; Crime na Adolescência; Aumento no Tempo na Escola; Efeitos de Incapacitação; Programa Mais Educação; Dados georreferenciados. 


\section{Table of contents}

$\begin{array}{lll}1 & \text { Introduction } & 10\end{array}$

2 Context, Data and Mais Educação $\quad 13$

2.1 Education in Brazil and São Paulo 13

2.2 Law enforcement 14

$\begin{array}{ll}\text { 2.3 The Mais Educação Program } & 15\end{array}$

3 Data and Empirical Strategy $\quad 19$

3.1 Data and sample 19

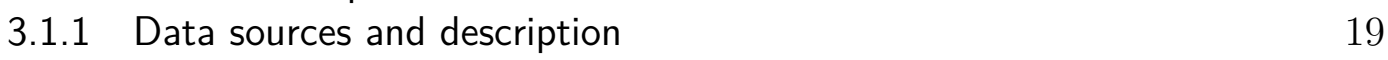

$\begin{array}{ll}3.1 .2 & \text { Final sample and descriptive statistics }\end{array}$

$\begin{array}{ll}3.2 & \text { Identification Strategy } \\ & 21\end{array}$

$\begin{array}{ll}3.3 & \text { Identification Threats }\end{array}$

4 Results $\quad 27$

4.1 Main Results $\quad 27$

4.2 Placebo checks 28

$\begin{array}{ll}4.3 \text { Heterogeneity in student vulnerability } & 29\end{array}$

5 Conclusions $\quad 36$

$\begin{array}{ll}\text { References } & 37\end{array}$

$\begin{array}{lll}\text { A Additional Tables and Figures } & 41\end{array}$ 


\section{List of figures}

Figure 2.1 Mais Educação phase-in - São Paulo 17

Figure 2.2 Mais Educação adoption in the state of São Paulo 18

Figure 3.1 Drug-crimes - Age Distribution 23

Figure 3.2 Discontinuity in program adoption 23

Figure 3.3 Discontinuity in share of students staying at least $6 \mathrm{~h} \quad 25$

Figure A.1 Artificial school districts - Examples 43

Figure A.2 Students +6 hours - Age Distribution 44

Figure A.3 9th grade IDEB 2009 scores - Histogram 44 


\section{List of tables}

Table 3.1 Descriptive Statistics by Mais Educação status 24

Table 3.2 First stage of program adoption on program outcomes 25

$\begin{array}{lll}\text { Table } 3.3 & \text { Discontinuity tests on covariates } & 26\end{array}$

Table 4.1 Reduced form results for different types of crime - extensive margin

Table 4.2 Reduced form results for subsamples of drug-related crimes - extensive margin

Table 4.3 Reduced form placebo tests for different types of crime

Table 4.4 Reduced form placebo tests for subsamples of drug-related crimes

Table 4.5 Heterogeneity in student vulnerability (\% in PBF) for different types of crimes

Table 4.6 Heterogeneity in student vulnerability (\% in PBF) for subsamples of drug-related crimes

Table A.1 Fields of Activities in PME - São Paulo

Table A.2 Reduced form results for different types of crime - intensive margin

Table A.3 Reduced form results for subsamples of drug-related crimes - intensive margin 


\section{Introduction}

Criminal activity increases in adolescence and peaks in early adulthood in both developed and developing countries. ${ }^{1}$ In addition to the ordinary social costs associated with crime, juvenile offenders also impose costs in terms of future criminal careers and opportunity costs related to skill and human capital formation. ${ }^{2}$ Previous work has shown criminal offenses in youth are important determinants of criminal behavior in adulthood, especially if it involves some type of incarceration (Aizer and Doyle Jr (2015), Bell et al. (2018a)). In particular, youths in developing countries may have high exposure to illegal markets and activities early in life, which can contribute to a career path in criminality (Sviatschi et al. (2017)). For example, entry age at Brazilian drug trafficking gangs can be as low as 11 years old and most offenders held in juvenile detentions in São Paulo report having committed their first crime before the age of 14 (Carvalho and Soares (2016), Sou da Paz (2018)).

Schooling is often pointed as a deterrent of criminal activity. ${ }^{3}$ Even though the negative correlation pattern between schooling and crime is wellestablished, interpreting this relationship as causal involves overcoming unobserved individual characteristics and reverse causality issues. ${ }^{4}$ In this paper, we ask whether extended school time affects criminal behavior. In a simple framework of time allocation decisions, decreasing available free time should prevent individuals from engaging in criminal activity. However, increased school time could simply displace crime over time or even turn otherwise law-abiding individuals into offenders due to extended social interactions and peer effects. To answer the proposed question we take advantage of a program in Brazil that increased school time in public schools throughout the country, Mais Educação. We tackle the endogeneity issues by exploiting a discontinuity in the

\footnotetext{
${ }^{1}$ Among other studies, see Levitt and Lochner (2001), Bell et al. (2018b), De Mello and Schneider (2010).

${ }^{2}$ Cunha et al. (2010) argue non-cognitive skills are important to determine crime outcomes and may be acquired interchangeably in early childhood and early adolescence.

${ }^{3}$ In Brazil, education is perceived as the most effective mechanism to reduce crime (Latinobarómetro 2010).

${ }^{4}$ For instance, patience and risk aversion may simultaneously affect decisions on crime and schooling. Also, there are credible estimates of the negative effect violent neighborhoods and incarceration have on educational attainment (See Damm and Dustmann (2014), Monteiro and Rocha (2017) and Aizer and Doyle Jr (2015))
} 
probability of receiving the program and use georeferenced crime data from the state of São Paulo to uncover its causal effects on criminal activity. We find there is a lower probability of observing less offensive crimes around schools at the treated side of the cutoff, with stronger evidence for drug-related crimes.

This paper broadly relates to the literature on the nonproduction benefits of schools, which has suggested that schools enhance civic engament and health outcomes (Lochner (2011), Oreopoulos and Salvanes (2011)). In particular, it adds to the literature on the schooling effects on crime. Theoretical contributions have highlighted that education increases the opportunity costs of engaging in criminal activity and may alter preferences and discount rates (Lochner (2010), Becker and Mulligan (1997)). Alongside gains in educational attainment and skill formation, schools also increase interactions among youth, which could have non trivial consequences to criminal behavior. Empirical contributions have convincingly shown educational attainment, school quality and positive peer effects reduce incarceration rates in adulthood (Lochner and Moretti (2004), Deming (2011), Billings et al. (2013), Machin et al. (2011))

Existing literature also advanced in understanding the contemporaneous effects of schools on juvenile crime. Billings et al. (2016) highlight the importance of peer effects in determining criminal behavior and is consistent with previous crime reducing results of attending high-achieving schools (Cullen et al. (2006)). Jacob and Lefgren (2003) use teacher in-service days to show violent crimes decrease when school is not in session, which is consistent with extended social interactions in schools. In contrast, they show that property crimes are higher in non-school days, consistent with an incapacitation mechanism for this type of crime. Berthelon and Kruger (2011) exploit a nationwide reform that extended daily school time in Chile and find evidence supporting the incapacitation effects of schools on both types of crimes. A number of other studies support the relevance of this mechanism mostly exploiting changes in the minimum dropout age, but also using teacher strikes as the source of exogeneity. (Anderson (2014), Beatton et al. (2018), Luallen (2006)).

In comparison to these contributions, we take advantage of a cleaner identification strategy to show the importance of the incapacitation effects of schools on drug-related crimes. Additionally, unlike most of previous work, we test the effects of schooling on juvenile crime using variation in the length of school day rather than in the length of school calendar year or minimum dropout age. Even though a cost-benefit analysis is beyond the scope of this article, this type of intervention may pose a relevant policy alternative in preventing youth crime. In this sense, this work also relates to studies with policy prescriptions on juvenile crime, which include different types of 
interventions such as conditional cash transfers and activities to foster changes in decision making (Sviatschi et al. (2017), Chioda et al. (2016), Heller et al. (2017)). In these cases, however, evidence on the incapacitation mechanism is rather limited.

Finally, this paper also connects to works on the effects of lengthening the school day on non-criminal outcomes. Almeida et al. (2016) use propensity score matching to assess the impact of early stages of Mais Educação on schooling outcomes and find negative impact on Math test scores. In addition to negative effects on crime, Berthelon and Kruger (2011) find that longer school days reduced the probability poor juveniles became adolescent mothers.

This paper is organized as follows. Section 2 provides background on education and law enforcement in Brazil by 2009, the year Mais Educação started in São Paulo, as well as the program description. Section 3 describes the data and outlines the empirical strategy. Section 4 presents the results and Section 5 concludes. 


\section{2}

\section{Context, Data and Mais Educação}

\section{1}

\section{Education in Brazil and São Paulo}

In Brazil, the regular school system is comprised of three stages: elementary, middle and high school. ${ }^{1}$ Free public provision is determined by the constitution, with municipalities responsible for the first phase and the states for the latter, with shared responsibility in middle school years. Schooling is compulsory for individuals aged between 6 and 17. Until the 90s, Brazil had struggled to enroll its children in school, but access to elementary school was almost universalized in the following decade. In 2009, $96.8 \%$ of individuals aged between 6 and 14 were in school in the country and São Paulo, Brazil's richest state, had an enrollment rate of $97.2 \%$. Nevertheless, the share outside school was still relatively high for older juveniles: 17.6\% aged between 15 and 17 did not attend classes in the country in this same year (they were $14.5 \%$ in São Paulo).

Although access to formal education has grown, Brazil still disappoints when it comes to student achievement, having ranked 50th among 61 nations in the 2009 PISA edition, below other Latin American countries such as Uruguay, Mexico and Chile. Accordingly, students often lag behind and are old compared to the right school age. In 2009, the national age-distortion index for public schools, calculated as the share of students who are at least two years older for their grade, was $32 \%$ in middle school and $38 \%$ in high school. São Paulo depicted a somewhat better picture, but still had respectively $14 \%$ and $19 \%$ of overaged students in these stages. Additionally, drop-out during the school year is also recurrent in Brazilian public schools, with $5.8 \%$ leaving school before the end of the year in middle school and $12.8 \%$ in high school. This problem is less severe in São Paulo, where $1.5 \%$ and $4.5 \%$ of pupils in middle and high school do not complete the school year in the state.

\footnotetext{
${ }^{1}$ Elementary school (Ensino Fundamental I) covers grades one to five and students aged between 6 and 10; Middle school (Ensino Fundamental II) covers grades six to nine and students aged between 11 and 14; High school (Ensino Médio) lasts three years and covers students aged between 15 and 17. Although it is not conventional in the country, we will call these high school grades as 10th, 11th and 12th grades.
} 
Unlike some developed countries, student allocation to schools does not follow a formal school district system in Brazil. States and cities are free to formulate their own sets of rules to determine where children ougth to attend classes. However, and crucial to this paper, São Paulo's education secretariat does assign pupils to schools based on their residence location (Chioda et al. (2016), Fernandes (2007)). Therefore, this paper creates artificial school districts as in Chioda et al. (2016), defining them as the area around a given school that is closest to that school relative to any other. ${ }^{2}$ Ultimately, this setting helps motivate the use of school as the unit of analysis in this paper.

Relevant to the empirical strategy, the main measure of school performance in Brazil is called IDEB - Índice de Desenvolvimento da Educação Básica. It is a biannual composite index that takes into account student performance in standardized tests and grade completion in a given schooling stage. Formally the IDEB score is calculated as follows:

$$
\mathrm{IDEB}_{\text {sit }}=\mathrm{N}_{\text {sit }} \cdot \mathrm{P}_{\text {sit }}
$$

where $N_{\text {sit }}\left(0 \leq N_{\text {sit }} \leq 10\right)$ is the average score of students in standardized Portuguese and Mathematics tests at stage $s$ of school $i$ in year $t$ and $P_{\text {sit }}$ is the average share of students that succesfully completed the school year in this same stage-school-year triple. These tests are typically taken by students at the end of each stage respectively at the 5 th, 9 th and 12 th grades. 9 th year IDEB results in 2009 are later used as running variable in the regression discontinuity design of interest. In that year, the score for public schools ranged from 0.7 to 8.0 points and averaged 3.7 in the country. São Paulo was the highest achieving state on average (4.3 points) with its worst and best school scoring respectively equal to 2.2 and 6.7 .

\section{2}

\section{Law enforcement}

The Brazilian constitution guards to state governments the responsibility for maintaining public safety and security. State governors usually include a security secretariat in their cabinet, which is mainly responsible to oversee the state Military and Civil police forces, independent corporations respectively responsible to ostensive patrolling and to conduct investigations on reported crimes. Municipalities' role in security issues is rather limited as local legislators

\footnotetext{
${ }^{2}$ Examples of artificial school districts are depicted for a neighborhood in São Paulo in Figure A.1 presented in Appendix A. Areas that are more than 2000 meters away from every school are not considered for any artificial school district.
} 
are allowed to create special municipal guard forces, but whose status is not comparable to the Military police force.

Importantly, crimes are reported to the Civil and Military Police through a BO - Boletim de Ocorrência, which contains information on day, time and location, and is used to open investigations. In general, the security secretariats compile and make this data publicly available. Unfortunately, only São Paulo's Security Secretariat provides information for this paper's relevant time period, which is the reason the analysis is restricted to this state.

In Brazil, the age of criminal responsibility is eighteen. Minors who commit crimes are subject to the norms of a special legislation, namely Estatuto da Criança e do Adolescente (ECA), which assigns child status to individuals under 12 and adolescent status to those between 12 and 18. Childs cannot be subject to punishment whatsoever, and in case of any misdemeanour authorities' responsibility is solely to communicate the parents. Adolescents, on the contrary, are subject to social-educational sanctions and, on extreme cases or recidivism, may be incarcerated in reeducation facilities for up to three years.

\section{3}

\section{The Mais Educação Program}

The Mais Educação program (or PME) was introduced in 2008 with the explicit goal to increase school time in Brazilian public schools. The program consisted in activities after regular classes for selected students and was financed by direct transfers from the federal government based on the number of students enrolled in the program. Resources were supposed to cover costs on personnel and needed materials.

In its early years, the Ministry focused on low achieving schools in large municipalities. In 2011, PME was relocated to a new division in MEC which defined the eligibility criteria more clearly, one of them being a cutoff rule based on the IDEB score. Specifically, schools with score lower or equal to the country's average in 2009 (3.7 points) would be eligible. School participation was not mandatory, but refusal by eligible schools had to be formally justified. Schools were somewhat free to choose among ten fields of activities they would offer after regular classes. For most part of the years, reinforcement classes in Math or Portuguese were mandatory and other after-school activities (e.g. sports, arts) could be selected by each school. Among the most picked fields of activities were Arts (30\%), Reinforcement Classes (27\%) and Sports (20\%). ${ }^{3}$

\footnotetext{
${ }^{3}$ Table A.1 in Appendix A shows the full list of fields of activities in 2011 and 2012.
} 
Schools were supposed to start offering the program in the beginning of school years. However, payments constantly stalled and anecdotal evidence suggest schools could take as long as one year to implement the program. Unfortunately, MEC did not collect data on program implementation, making it more difficult to understand when each school started offering extra classes and whether students were indeed staying longer in schools. INEP's School Census helps alleviate this problem, although the annual frequency of its data does not provide the ideal level of detail. We discuss this issue in more detail in the next session.

Regarding the actual treatment recipients, schools were free to choose program participants and any student in a Mais Educação school could be selected, although MEC suggested the enrollment of at least 100 students and priority to those in middle school years who were likely to dropout. Without official data on recipient characteristics, we rely on the School Census to understand who was staying longer in schools. Indeed, the program seems to have had most impact on students in middle school since the median age of students staying at least six hours in PME schools was 13 years old. ${ }^{4}$

Figure 2.1 uses MEC data to show the evolution of school and student enrollment in the program in São Paulo. Participation was low in 2009, increased in 2011 and 2012, the relevant years to this paper, and reached more than 30 percent of São Paulo's public schools in 2014. In regards to school location, Figure 2.2 shows adoption was concentrated in the metropolitan area of the capital at first, but spread out to the rest of the state in the following years.

\footnotetext{
${ }^{4}$ Figure A.2 in the Appendix A shows the age histogram for students who stay longer
} than six hours at schools. 
Figure 2.1: Mais Educação phase-in - São Paulo
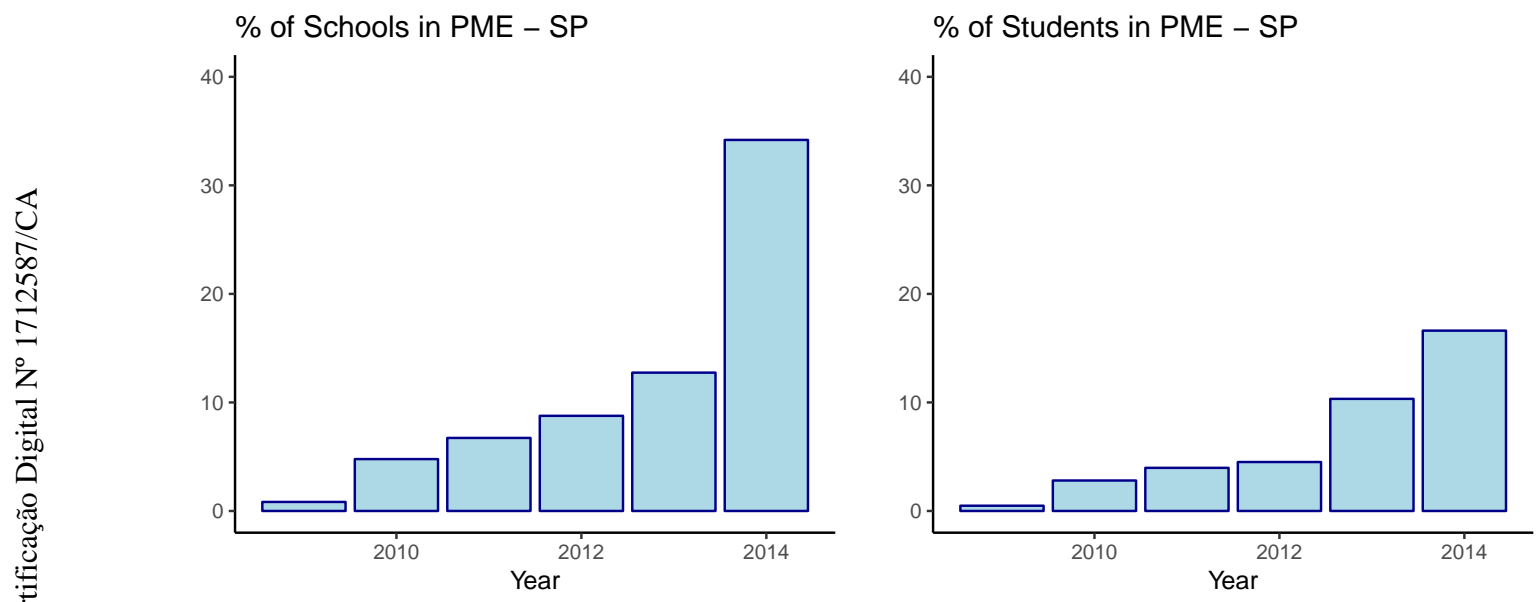

Notes: This Figure plots Mais Educação's phase-in for São Paulo schools. Y-axis refer respectively for the share of public schools adopting the program and the share of students in São Paulo's public school system officially enrolled in PME. Each bar comprises information for one year from 2009 to 2014. 
Figure 2.2: Mais Educação adoption in the state of São Paulo
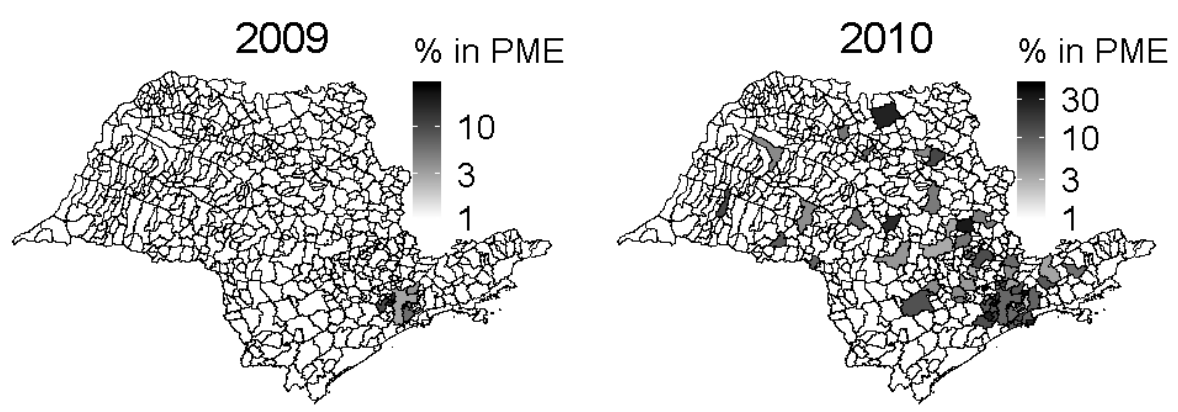

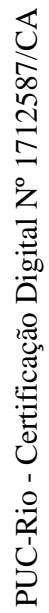
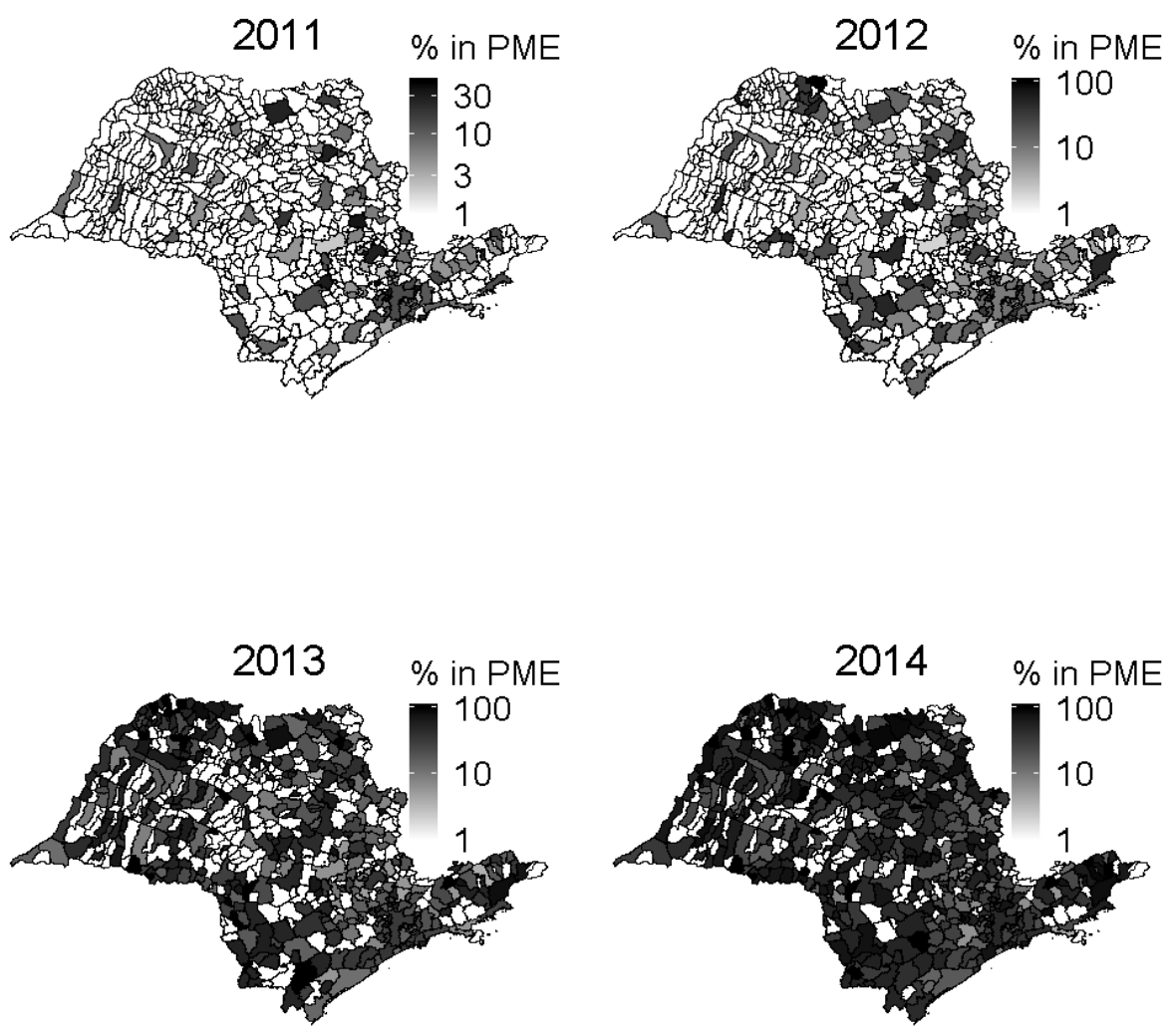

Notes: This Figure plots Mais Educação's geographical phase-in in São Paulo. Each map shows the share of public schools that have adopted PME in a given municipality from 2009 to 2014. Scales differ between maps. 


\section{3 \\ Data and Empirical Strategy}

\section{1}

\section{Data and sample}

\subsection{1}

\section{Data sources and description}

To perform the proposed analysis, we gather data from different sources. Official data from the Ministry of Education provides annual information on schools in the program, such as the number of enrolled students, type of selected activities and the sum transferred to each school between 2008 and 2014. From the School Census, it is possible to know how long each student is supposed to stay in school as well as other important school, employee and student characteristics. The IDEB score, which the cutoff rule is based, is also compiled by INEP every two years. Coordinates for most public schools throughout the state of São Paulo are provided by the state and municipal education secretariats. The remainder is georeferenced based on the address provided by the same secretariats.

As previously mentioned, the security secretariat of São Paulo provides data on reported crimes for a variety of types: homicide, property and drugrelated crimes. This dataset contains information on day, time and coordinates for most reported crimes starting in 2010. Again, we georeference crimes for which only the address is available. Importantly, for drug-related crimes there is also information on offender's age and occupation.

The drug crime-age profile in the sample is shown in Figure 3.1. There is a considerably high number of reports for under eighteen years old as the distribution peaks at the age 17 before smoothly decreasing for older individuals. Interestingly, the fraction of drug-crimes committed by students is somewhat large in the sample, $12.6 \%$, and close to the fraction of offenders who are unemployed, $14.3 \%$.

Making use of the precise location of each crime and school, combined with São Paulo's pupil allocation system, we attribute a crime to a school if it falls within an artificial school district boundary, in the spirit of Chioda et al. (2016). Then, crimes are aggregated for each year. 


\subsection{2}

\section{Final sample and descriptive statistics}

Two important sample restrictions are made prior to arriving to our final sample. First, the reported crime data covered most but not all municipalities in the state. Therefore, schools in municipalities for which there is not a single reported crime reported in 2011 are excluded from the sample. Additionally, because another relevant rule in 2011 gave priority to schools which have already been in the program in prior years, we drop these schools in order to have a cleaner comparison group. Importantly, sample selection should not be a major worry to the proposed identification strategy provided variation around the cutoff is as good as random.

Table 3.1 compares the descriptive statistics of schools that have and have not received Mais Educação resources in 2011. It is straightforward to notice that schools are different in a variety of dimensions. PME schools are larger in terms of students and infrastructure, and have poorer, worse performing students on average. Additionally, the probability of observing homicide, cellphone and vehicle related crimes are higher around these schools. Therefore, a naive OLS estimation of the effects of the program on crime would likely produce biased estimates even when controlling for observables. These different school characteristics motivates an identification strategy in which both control and treatment groups are comparable also in unobservable characteristics. As previously mentioned, a cutoff rule gave priority to schools with IDEB score in 2009 below 3.7 points and is used to provide a cleaner comparison between schools.

As mentioned in previous sections, anecdotal evidence of late program implementation by the schools combined with late payments from MEC gives a degree of uncertainty of the precise moment the schools actually started offering the extended hours. Therefore, to better capture the effects of Mais Educação adoption on school time outcomes, we use school information from both 2011 and 2012. To assess its causal effects on crime, we also rely on data from these two years.

Figure 3.2 and the first row of Table 3.2 show the discontinuity in the program adoption, with a jump of around 17 percentage points in the probability of receiving the program for schools just below the 3.7 cutoff.

As expected, official MEC data shows the number of enrolled students and the amount directly transferred also jumps discontinuously at the cutoff. The effect the program has on these variables is an increase of around 10 times for schools just before the cutoff compared to schools just after. INEP's data confirms the share of students staying longer at schools jumps discontinuously. 
Although estimates are less precise and somewhat smaller, the program does seem to have induced a great number of students to extend their school time. Figure 3.3 provides visual evidence.

\section{2}

\section{Identification Strategy}

We are interested in testing whether extended school time affects contemporaneous crime using variation induced by the Mais Educação program. Even though the program was not randomized, our setting provides quasiexperimental variation in the vicinitiy of the cutoff. In the following section, we argue this is indeed a valid strategy. Using the regression discontinuity framework, we take advantage of this rule by estimating the following reduced-form equation:

$$
\mathrm{Crime}_{i t c}=\alpha+\beta \mathrm{I}\left(\mathrm{IDEB}_{2009} \leq 3.7\right)_{i}+f\left(\mathrm{IDEB}_{2009}-3.7\right)_{i}+\delta_{t}+\gamma_{c}+\epsilon_{i t c}
$$

The dependent variable Crime $_{i t c}$ refers to either the extensive or intensive margin of a given type of crime in school district $i$, year $t$ and region $c$. This specification adds year and region fixed effects, where region is a binary indicator of state capital. In the main specification, function $f(\cdot)$ is a linear function allowed to vary in parameters on both sides of the cutoff.

In short, we compare crime outcomes in schools which scored barely below the IDEB cutoff to outcomes in schools which scored barely above the cutoff. Because of partial take-up, $\hat{\beta}$ is an ITT estimator.

\section{3}

\section{Identification Threats}

As previously mentioned, the outlined empirical strategy will only capture the true causal effect of school time on crime provided variation in IDEB at the cutoff is as good as random. Therefore, the main threat to this identification strategy is any systematic difference between schools that are in the vicinity but in different sides of the cutoff or another policy that is tied to the same cutoff rule. Importantly, if schools can perfectly control their IDEB score they may self select into or out of treatment and ultimately undermine the identifying assumption. As explained in section 3.1, the nature and timing of the criteria does not suggest any manipulation to be likely, making it unfeasible to schools to self select to the treatment. Indeed, two manipulation tests suggest sorting to one of the sides of the cutoff is unlikely. The null hypothesis of no manipulation cannot be rejected using density tests proposed by McCrary 
(2008) and Cattaneo et al. (2018) (p-values of 0.72 and 0.46 , respectively). ${ }^{1}$

Even though self selection does not seem to be a problem, schools right before the cutoff are less likely to be from the capital of the state. Because schools in the city of São Paulo may differ from the remainder of the state, the inclusion of a dummy variable to indicate whether the school is located in the capital is made necessary. By doing this, we ensure comparison is made within schools in the capital and within the rest of the state, although the main results are considerably the same in the absence of this dummy. Additionally, it is important to check whether schools are comparable on observables on the two sides of the cutoff. Thus, we test the continuity of a number of covariates prior to treatment. Although it is impossible to exhaust all relevant dimensions, the results in Table 3.3 show schools do indeed look similar around the cutoff in a variety of aspects, such as student, school and crime characteristics. Importantly, the sum of other direct transfers from the federal government does not change discontinuously at the cutoff, which is suggestive of the absence of any other program following the same cutoff rule.

${ }^{1}$ Figure A.3 in Appendix A provides visual evidence using a thin binned histogram. 
Figure 3.1: Drug-crimes - Age Distribution

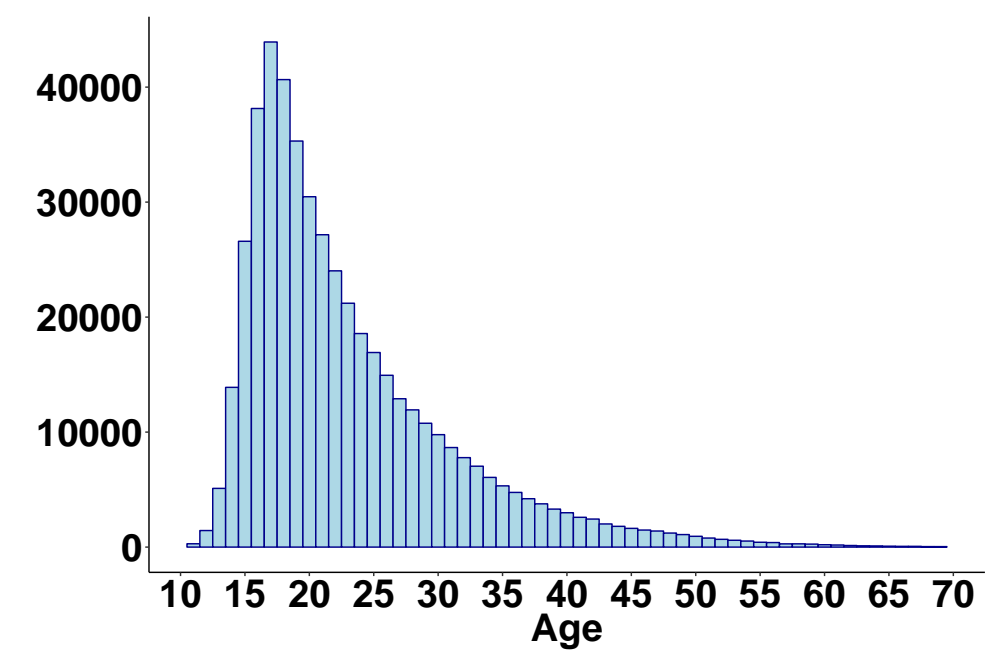

Notes: This Figure plots a histogram of drug crimes in the sample by age using reported data from 2011 to 2014 . Each bin counts the number of crimes committed for a certain age. The mode is 17 years old.

Figure 3.2: Discontinuity in program adoption

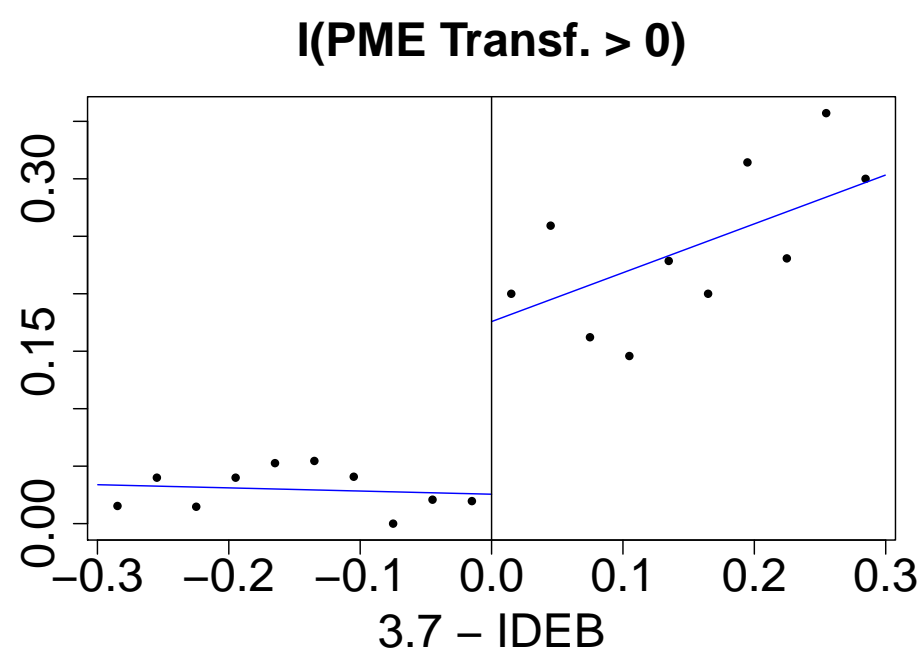

Notes: This Figure plots the probability of observing schools in Mais Educação for each bin of width 0.03 . Y-axis variable is an indicator of PME transfers in 2011. Running variable is 9th year IDEB score of 2009 centered at 3.7. The plot also features the fitted values from a local linear regression model estimated separately on each side of the cutoff point. 
Table 3.1: Descriptive Statistics by Mais Educação status

\begin{tabular}{|c|c|c|c|c|c|}
\hline & Not in PME & $\begin{array}{c}(2) \\
\text { In PME }\end{array}$ & $\begin{array}{c}(3) \\
(2)-(1)\end{array}$ & $\begin{array}{c}(4) \\
\text { P-value }\end{array}$ & $\begin{array}{l}(5) \\
\mathrm{N} \\
\end{array}$ \\
\hline $\mathrm{N}$ & 3,500 & 218 & 3,282 & 0 & 3,718 \\
\hline \multicolumn{6}{|l|}{ Student Characteristics } \\
\hline Total Students & 982.551 & $1,043.927$ & 61.376 & 0.053 & 3,718 \\
\hline Students (5th-12th) & 921.592 & 943.404 & 21.812 & 0.467 & 3,718 \\
\hline Students (5th-9th) & 627.654 & 681.523 & 53.869 & 0.008 & 3,718 \\
\hline Students/Class (5th-9th) & 32.794 & 31.713 & -1.081 & 0.000 & 3,718 \\
\hline Over-age Students (5th-9th) $(\%)$ & 13.101 & 19.748 & 6.647 & 0.000 & 3,718 \\
\hline Passing Rate (5th-9th) (\%) & 92.272 & 87.740 & -4.533 & 0.000 & 3,718 \\
\hline Drop-out Rate (5th-9th) (\%) & 1.563 & 2.739 & 1.177 & 0.000 & 3,718 \\
\hline IDESP (5th-9th) & 2.603 & 1.930 & -0.673 & 0.000 & 2,697 \\
\hline IDEB (5th-9th) & 4.370 & 3.634 & -0.736 & 0.000 & 3,718 \\
\hline Share in $\mathrm{PBF}$ & 0.200 & 0.237 & 0.037 & 0.000 & 3,718 \\
\hline \multicolumn{6}{|l|}{ School Characteristics } \\
\hline Municipal School & 0.266 & 0.362 & 0.097 & 0.002 & 3,718 \\
\hline Library & 0.121 & 0.165 & 0.044 & 0.056 & 3,718 \\
\hline Classrooms/Students & 0.017 & 0.019 & 0.002 & 0.001 & 3,718 \\
\hline Computers/Students & 0.033 & 0.039 & 0.005 & 0.095 & 3,712 \\
\hline Internet Connection & 0.993 & 0.991 & -0.002 & 0.734 & 3,712 \\
\hline Employees/Students & 0.084 & 0.091 & 0.007 & 0.000 & 3,718 \\
\hline Teachers w/ College Degree (\%) & 98.203 & 97.922 & -0.281 & 0.234 & 3,718 \\
\hline PDDE Direct Transfers & $12,757.520$ & $66,285.680$ & $53,528.160$ & 0.000 & 3,718 \\
\hline \multicolumn{6}{|l|}{ Crime (Overall) } \\
\hline Homicides (\%) & 29.254 & 44.393 & 15.138 & 0.000 & 3,393 \\
\hline Cell phone crimes $(\%)$ & 90.280 & 96.262 & 5.982 & 0.004 & 3,393 \\
\hline Vehicle crimes $(\%)$ & 86.662 & 91.589 & 4.926 & 0.038 & 3,393 \\
\hline \multicolumn{6}{|l|}{ Crime (School time) } \\
\hline Homicides (\%) & 6.354 & 9.813 & 3.459 & 0.048 & 3,393 \\
\hline Cell phone crimes (\%) & 77.980 & 87.850 & 9.870 & 0.001 & 3,393 \\
\hline Vehicle crimes $(\%)$ & 68.103 & 75.234 & 7.130 & 0.030 & 3,393 \\
\hline
\end{tabular}

Notes: Student Characteristics: Total Students, Students (5th-12th), Students (5th9th), Students/Class and Over-age Students (5th-9th), and Share in PBF refer to the 2011 school year; Passing Rate (5th-9th), Drop-out Rate (5th-9th), Retention Index (5th-9th) and IDESP (5th-9th) refer to the 2010 school year. All but IDESP, IDEB and Share in PBF are taken from the School Census. IDESP is a composite score similar to IDEB but compiled by the State of São Paulo. Share in PBF refers to share of students from families on Bolsa Familia, a nationwide conditional cash transfer program. School Characteristics: PDDE Direct Transfers is taken from MEC and refers to the sum transferred directly to schools in 2011 including resources to fund extended school time. The remainder is taken from INEP's School Census of 2011. Crime: Homicides refer to different classifications of homicides, Cell phone crimes refer to robberies and thefts of cell phones and vehicle crimes refer to robberies and thefts of vehicles reported in 2010. Overall crime refers to crimes occurred in any time and day of the year. School time crimes refer to crimes committed on school days between $6 \mathrm{am}$ and $6 \mathrm{pm}$. The number of observations drops in the crime outcomes due to limited crime data coverage in 2010 . 
Table 3.2: First stage of program adoption on program outcomes

\begin{tabular}{|c|c|c|c|c|}
\hline & Coef. (Control Gr.) & I(IDEB <3.7) & BW & $\mathrm{n}$ \\
\hline P(Mais Educação) & 0.022 & $\begin{array}{c}0.174^{* * *} \\
(0.051)\end{array}$ & 0.374 & 1,166 \\
\hline Enrolled students & 17.094 & $\begin{array}{c}181.924^{* * *} \\
(64.864)\end{array}$ & 0.307 & 2,020 \\
\hline PME Direct Transfers & $2,822.972$ & $\begin{array}{c}26739.629^{* * *} \\
(6,945.248)\end{array}$ & 0.313 & 2,058 \\
\hline$\%$ Students $+6 \mathrm{~h}$ & 0.031 & $\begin{array}{c}0.126 \\
(0.082)\end{array}$ & 0.336 & 2,214 \\
\hline$\%$. Students $+6,5 \mathrm{~h}$ & 0.027 & $\begin{array}{c}0.105 \\
(0.082)\end{array}$ & 0.343 & 2,258 \\
\hline$\%$ Students $+7 \mathrm{~h}$ & 0.023 & $\begin{array}{c}0.100 \\
(0.083) \\
\end{array}$ & 0.345 & 2,266 \\
\hline
\end{tabular}

Notes: P(Mais Educação) refers to the probability of receiving resources to fund the program in 2011. The other rows take into account the school take up, i.e. refer to fuzzy regression discontinuities in which the first stage is the probability of program adoption by schools and use data from 2011 and 2012. The first three rows make use of official MEC data and the remainder uses data from INEP's School Census. Regressions include a year and region fixed effects and standard errors are clustered at the school level. Total number of observations is 3,718 in the first regression and 7,436 in the other ones. ${ }^{* * *} \mathrm{p}<0.01,{ }^{* *} \mathrm{p}<0.05,{ }^{*} \mathrm{p}<0.1$.

Figure 3.3: Discontinuity in share of students staying at least $6 \mathrm{~h}$

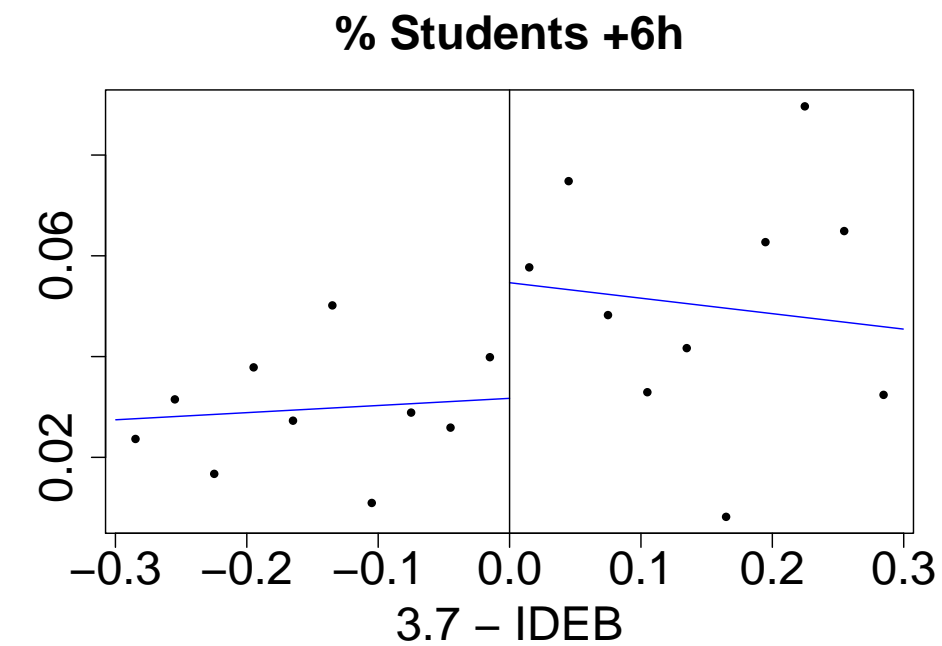

Notes: This Figure plots the share of students staying at least 6 hours in schools for each bin of width 0.03 . Y-axis variable is the share of Students staying at least 6 hours in schools in 2011 and 2012. Running variable is 9 th year IDEB score of 2009 centered at 3.7. The plot also features the fitted values from a local linear regression model estimated separately on each side of the cutoff point. 
Table 3.3: Discontinuity tests on covariates

\begin{tabular}{|c|c|c|c|c|c|}
\hline & Coef. Cont. & $\mathrm{I}(\mathrm{IDEB}<3.7)$ & & BW & $\mathrm{n}$ \\
\hline \multicolumn{6}{|l|}{ Student Characteristics } \\
\hline Total Students (log) & 6.930 & -0.091 & $(0.083)$ & 0.330 & 1,084 \\
\hline Students (5th-12th) (log) & 6.848 & -0.093 & $(0.079)$ & 0.360 & 1,172 \\
\hline Students (5th-9th) (log) & 6.459 & -0.079 & $(0.073)$ & 0.403 & 1,296 \\
\hline Students/Class (5th-9th) (log) & 3.537 & $-0.042^{* *}$ & $(0.023)$ & 0.270 & 882 \\
\hline Over-age Students (5th-9th) (\%) & 16.226 & 0.891 & $(1.168)$ & 0.298 & 972 \\
\hline Passing Rate (5th-9th) (\%) & 89.038 & 0.018 & $(0.998)$ & 0.271 & 884 \\
\hline Drop-out Rate (5th-9th) (\%) & 2.346 & -0.276 & $(0.492)$ & 0.268 & 878 \\
\hline IDESP (5th-9th) & 2.079 & -0.007 & $(0.073)$ & 0.274 & 674 \\
\hline Share in $\mathrm{PBF}$ & 0.234 & 0.004 & $(0.017)$ & 0.298 & 972 \\
\hline \multicolumn{6}{|l|}{ School Characteristcs } \\
\hline Municipal School & 0.294 & -0.066 & $(0.058)$ & 0.404 & 1,297 \\
\hline Library & 0.099 & 0.053 & $(0.051)$ & 0.393 & 1,270 \\
\hline Classrooms/Students & 0.016 & $0.002^{*}$ & $(0.001)$ & 0.329 & 1,083 \\
\hline Computers/Students & 0.030 & -0.001 & $(0.003)$ & 0.299 & 971 \\
\hline Internet & 0.988 & -0.007 & $(0.017)$ & 0.555 & 1,742 \\
\hline Employees/Students & 0.085 & 0.001 & $(0.005)$ & 0.392 & 1,268 \\
\hline Teachers w/ College (\%) & 97.861 & -0.685 & $(0.572)$ & 0.350 & 1,144 \\
\hline PDDE Direct Transfers (Total) & $18,999.610$ & 1800.326 & $(2941.344)$ & 0.294 & 964 \\
\hline \multicolumn{6}{|l|}{ Crime (Overall) } \\
\hline Homicides (\%) & 38.478 & -10.545 & $(8.46)$ & 0.223 & 682 \\
\hline Cell phone crimes (\%) & 91.722 & -1.963 & $(4.059)$ & 0.460 & 1,376 \\
\hline Vehicle crimes $(\%)$ & 87.88 & 2.432 & $(4.323)$ & 0.450 & 1,341 \\
\hline \multicolumn{6}{|l|}{ Crime (School days 6am-6pm) } \\
\hline Homicides (\%) & 10.741 & -2.667 & $(4.472)$ & 0.430 & 1,278 \\
\hline Cell phone crimes $(\%)$ & 80.995 & -6.426 & $(6.018)$ & 0.415 & 1,239 \\
\hline Vehicle crimes (\%) & 66.486 & 5.137 & $(7.011)$ & 0.356 & 1,092 \\
\hline
\end{tabular}

Notes: Column (1) refers to the estimated coefficient at the cutoff for the control group, Column (2) refers to the jump at the cutoff for the treatment group, Column (3) refers to clustered standard errors at the school level, Column (4) refers to CCT's optimal bandwidth and Column (5) refers to the number of observations used. Total number of observations is the same as in Table 3.1.

Student Characteristics: Total Students, Students (5th-12th), Students (5th-9th), Students/Class and Over-age Students (5th-9th), and Share in PBF refer to the 2011 school year; Passing Rate (5th-9th), Drop-out Rate (5th-9th), Retention Index (5th-9th) and IDESP (5th-9th) refer to the 2010 school year. All but IDESP and Share in PBF are taken from the School Census. IDESP is a composite score similar to IDEB but compiled by the State of São Paulo. Share in PBF refers to share of students from families on Bolsa Familia, a nationwide conditional cash transfer program. School Characteristics: PDDE Transfers is taken from MEC and refers to the sum transferred directly to schools in 2011 excluding resources to fund extended school time. The remainder is taken from INEP's School Census of 2011. Crime: Homicides refer to different classifications of homicides, Cell phone crimes refer to robberies and thefts of cell phones and vehicle crimes refer to robberies and thefts of vehicles reported in 2010. Overall crime refers to crimes occurred in any time and day of the year. School time crimes refer to crimes committed on school days between 6am and $6 \mathrm{pm}$.

The regressions include a dummy to indicate whether a school is in the capital of the state or not. ${ }^{* * *} \mathrm{p}<0.01,{ }^{* *} \mathrm{p}<0.05,{ }^{*} \mathrm{p}<0.1$. 


\section{Results}

\section{1}

\section{Main Results}

Table 4.1 and 4.2 present the results of the reduced form estimation of equation 3-1 on different crime outcomes for crimes when school is in session. Because of the low frequency of crimes around school areas, the dependent variable in our main specifications are binary indicators of reported crime for different types of felonies or misdemeanors. The first table shows the results in the extensive margin for total crimes by type of offense, whereas the following table depicts the results in the probability of observing drug crimes for different subsamples, since we have detailed offender information for this type of crime. ${ }^{1}$ The nature of the analyzed crimes suggests an intervention at school-aged juveniles would most likely affect less offensive crimes such as thefts and robberies of mobile phones and drug crimes. Indeed, the point estimates referring to homicides and vehicle thefts and robberies are essentially zero. As expected, the only types of crime that seem to respond negatively to increased school time are the ones related to mobile phones and drug crimes as depicted in Table 4.1, with large point estimates but marginally not statistically significant.

These results are not unsurprising since we did not distinguish between crimes committed by school-aged juveniles and by older individuals unlikely to be affected by the program. Although limited information on offender characteristics prevents further tests on thefts and robberies of mobile phones, data on drug crimes does provide information on age and occupation of the offender allowing us to refine the results to the population of interest. The different columns of Table 4.2 presents results for these different subsamples. With age and occupation information, it would be expected that students under the age of 18 (column 2) to be the group affected the most by the increase in school time, followed by under 18 years old in general (column 1). Unless the

\footnotetext{
${ }^{1}$ Tables A.2 and A.3 in Appendix A replicates the main regression results for the intensive margin, with the total number of reported crimes per thousand students as the dependent variable. Overall crime rates, along with the subsamples of drug related crimes, do not seem to respond to increased school time in the intensive margin.
} 
illegal drug market was greatly affected by the time students spend in school, it would not be expected that criminal activity of the above 25 years old group (column 3) to vary between control and treatment groups. Interestingly, this pattern is precisely the one that emerges at the regressions shown in this table, with students under 18 being 6 percentage points less likely to have committed a drug crime in the treated side of the cutoff, although this point estimate is only slightly significant. Reassuringly, the results for the subsample of offenders aged above 25 do not change discontinously at the cutoff.

\section{2 \\ Placebo checks}

The observed pattern in the previous session is consistent with an incapacitation mechanism of schools. Importantly, in order to make sure incapacitation is indeed the relevant underlying mechanism, we test whether crime patterns differ among groups when school is not in session. Table 4.3 and 4.4 report the extensive margin results of this placebo test respectively on overall reported crimes and for the subsamples of the drug crime dataset. The different panels report results for two subsamples that differ on the timing of the offense: crimes between 6am and 6pm on non-school days (Panel A) and crimes before and after school time on school days (Panel B). We consider the first to be the preferred placebo test since an intervention in the length of school days that is expected to have contemporaneous effects on crime is unlikely to have any influence on crime patterns on weekends or holidays, whereas the latter may still capture indirect effects of changes in school dynamics that are complementary to direct effects of incapacitation (for instance, individuals may be more tired after longer school days).

Table 4.4 confirms there is no systematic fall in the probability of observing drug crimes when school is not in session for the subsamples of interest. Combined with what was shown in the previous session, these results are consistent with the drug crime reducing incapacitation mechanism of schools. Importantly, there also does not seem to be a displacement over time for this type of crime as the estimated effects are essentially zero. For the more aggregated dataset, Panel (A) of Table 4.3 adds to the incapacitation mechanism story, although Panel (B) shows there is a lower probability of observing overall drug, vehicle and cell phone crimes on any time of school days. Regarding mobile phones-related crimes, the point estimate is virtually the same as in Table 4.1, which is not inconsistent with incapacitation, but does require a complementary explanation we are unable to test. Similarly, vehicle-related crimes drop during school days while school is not in session, 
which may be due to particular crime opportunities and characteristics of this type of crime, although it is also hard to test its connection to extended school days.

In short, these placebo checks are consistent with an incapacitation effect of school on crimes, with greater evidence on drug-related ones, for which we have more detailed information. This type of crime drops for students under the age of 18 during school hours, but not when school is not in session. Combined with the lack of such effect for individuals who are over 25 years old, this is strong evidence for the incapacitation mechanism.

\section{3}

\section{Heterogeneity in student vulnerability}

In this section, we analyze whether there is any heterogeneity in the results in regards to student vulnerability, proxied as the share of students on Bolsa Família (PBF), Brazil's nationwide conditional cash transfer program. The sample is split in schools with share of students on PBF above or below the median (18.7\%). We conduct the same reduced form regressions as before for all types of crimes and Table 4.5 and 4.6 present the results, where Panel (A) refers to the subsample with share of students above the median and Panel (B) refers to the other subsample.

Interestingly, even though results in Table 4.1 were not statistically different from zero, the large point estimates seem to have been driven by schools with poorer students as Table 4.5 reports statistically significant negative estimates for overall mobile phone and drug-related crimes for schools where student vulnerability is high, but not in Panel (B) for schools with less students in PBF. These differences among groups are not as robust for the subsample of students under the age of 18 , although the point estimate is also higher for schools with share of students in PBF above the median.

These results are interesting for at least two reasons. First, the conditionality of PBF transfers provides incentives to children's attendance in schools, which mitigates the lack of information on actual student take-up in the program, thus supporting the incapacitation mechanism. Second, because youth in poorer neighborhoods may be closer to illegal activities and drug trafficking gangs, extending their time in school may divert them from illegal behavior early in their life and prevent them from following a career path in crime, thus adding to the social benefits of increasing time spent in school. 
Table 4.1: Reduced form results for different types of crime - extensive margin

Crimes on school days between 6am-6pm

\begin{tabular}{lcccc}
\hline Dep. Var.: I(Crimes $>0)$ & & \\
\hline & Homicide & Vehicle \\
& $(1)$ & $(2)$ & $(3)$ & $(4)$ \\
\hline I(IDEB $\leq 3.7)$ & 1.251 & 1.157 & -6.212 & -6.935 \\
& $(2.453)$ & $(4.379)$ & $(4.141)$ & $(4.813)$ \\
Mean Cont. & 11.287 & 68.665 & 81.949 & 63.046 \\
BW & 0.467 & 0.326 & 0.281 & 0.270 \\
$\mathrm{n}$ & 2996 & 2148 & 1826 & 1764 \\
$\mathrm{n}$ (total) & 7436 & 7436 & 7436 & 7436 \\
\hline
\end{tabular}

Notes: Reduced form local linear regressions with CCT's optimal bandwidth and triangular Kernel. All regressions include year and region dummies and clustered standard errors at the school level. Mean Cont. refers to estimated coefficient at the left of the cutoff. Column one refers to different classifications of homicides; Column two refers to vehicle thefts and robberies; Column three refers to mobile phone thefts and robberies; Column four refers to drug crimes. Dependent variable takes one if the number of crimes on school days between $6 \mathrm{am}$ and $6 \mathrm{pm}$ is greater than zero.*** $\mathrm{p}$ $<0.01,{ }^{* *} \mathrm{p}<0.05,{ }^{*} \mathrm{p}<0.1$. 
Table 4.2: Reduced form results for subsamples of drug-related crimes extensive margin

\section{Crimes on school days between 6am-6pm}

\begin{tabular}{lccc}
\hline \multicolumn{4}{c}{ Dep. Var.: I(Drug Crimes $>0)$} \\
& $\begin{array}{c}\text { Under 18s } \\
(1)\end{array}$ & $(2)$ & $(3)$ \\
\hline I(IDEB $\leq 3.7)$ & -1.02 & $-6.148^{*}$ & 0.948 \\
& $(3.768)$ & $(3.47)$ & $(4.469)$ \\
Mean Cont. & 34.792 & 23.110 & 25.551 \\
BW & 0.401 & 0.335 & 0.268 \\
n & 2584 & 2204 & 1746 \\
n(total) & 7436 & 7436 & 7436
\end{tabular}

Notes: Reduced form local linear regressions with CCT's optimal bandwidth and triangular Kernel. All regressions include year and region dummies and clustered standard errors at the school level.Mean Cont. refers to estimated coefficient at the left of the cutoff. Column one refers to individuals under 18; Column two refers to the subsample of students under 18; Column three refers to individuals above 25. Dependent variable takes one if the number of drug crimes on school days between $6 \mathrm{am}$ and $6 \mathrm{pm}$ is greater than zero. ${ }^{* * *} \mathrm{p}<0.01,{ }^{* *} \mathrm{p}<0.05,{ }^{*} \mathrm{p}<0.1$. 
Table 4.3: Reduced form placebo tests for different types of crime

Dep. Var.: $\mathrm{I}($ Crimes $>0)$

Panel A: Non-school days between 6am and 6pm

\begin{tabular}{|c|c|c|c|c|}
\hline & $\begin{array}{c}\text { Homicide } \\
(1)\end{array}$ & $\begin{array}{c}\text { Vehicle } \\
(2)\end{array}$ & $\begin{array}{c}\text { Mobile Phone } \\
(3) \\
\end{array}$ & $\begin{array}{c}\text { Drug } \\
(4) \\
\end{array}$ \\
\hline $\mathrm{I}(\mathrm{IDEB} \leq 3.7)$ & $\begin{array}{l}-2.490 \\
(2.563)\end{array}$ & $\begin{array}{c}0.020 \\
(4.896)\end{array}$ & $\begin{array}{l}-4.405 \\
(4.354)\end{array}$ & $\begin{array}{c}0.261 \\
(5.484)\end{array}$ \\
\hline Mean Cont. & 11.261 & 65.503 & 75.955 & 46.522 \\
\hline BW & 0.259 & 0.297 & 0.290 & 0.205 \\
\hline $\mathrm{n}$ & 1680 & 1944 & 1908 & 1340 \\
\hline$\underline{n(\text { total })}$ & 7436 & 7436 & 7436 & 7436 \\
\hline \multicolumn{5}{|c|}{ Panel B: School days before 6am and after 6pm } \\
\hline & $\begin{array}{l}\text { Homicide } \\
\text { (1) }\end{array}$ & $\begin{array}{c}\text { Vehicle } \\
(2)\end{array}$ & $\begin{array}{c}\text { Mobile Phone } \\
(3)\end{array}$ & $\begin{array}{c}\text { Drug } \\
(4)\end{array}$ \\
\hline $\mathrm{I}(\mathrm{IDEB} \leq 3.7)$ & $\begin{array}{c}0.934 \\
(2.679)\end{array}$ & $\begin{array}{c}-8.765^{* *} \\
(4.816)\end{array}$ & $\begin{array}{l}-6.855^{*} \\
(4.094)\end{array}$ & $\begin{array}{c}-11.688^{* *} \\
(5.5)\end{array}$ \\
\hline Mean Cont. & 18.159 & 75.945 & 79.351 & 51.689 \\
\hline BW & 0.424 & 0.262 & 0.309 & 0.229 \\
\hline $\mathrm{n}$ & 2706 & 1710 & 2026 & 1492 \\
\hline $\mathrm{n}($ total $)$ & 7436 & 7436 & 7436 & 7436 \\
\hline
\end{tabular}

Notes: Reduced form local linear regressions with CCT's optimal bandwidth and triangular Kernel. All regressions include year and region dummies and clustered standard errors at the school level. Mean Cont. refers to estimated coefficient at the left of the cutoff. Column one refers to different classifications of homicides; Column two refers to vehicle thefts and robberies; Column three refers to mobile phone thefts and robberies; Column four refers to drug crimes. Dependent variable in Panel (A) takes one if the number of crimes on non-school days between $6 \mathrm{am}$ and $6 \mathrm{pm}$ is greater than zero Dependent variable in Panel (B) takes one if the number of crimes on school days before $6 \mathrm{am}$ and after $6 \mathrm{pm}$ is greater than zero. ${ }^{* * *} \mathrm{p}<0.01,^{* *} \mathrm{p}$ $<0.05,{ }^{*} \mathrm{p}<0.1$. 
Table 4.4: Reduced form placebo tests for subsamples of drug-related crimes

Dep. Var.: I(Drug Crimes $>0$ )

\begin{tabular}{|c|c|c|c|}
\hline \multicolumn{4}{|c|}{ Panel A: Non-school days between 6am and 6pm } \\
\hline & $\begin{array}{c}\text { Under } 18 \mathrm{~s} \\
(1)\end{array}$ & $\begin{array}{c}\text { Under } 18 \mathrm{~s} \text { - Students } \\
(2)\end{array}$ & $\begin{array}{c}\text { Above } 25 \mathrm{~s} \\
(3)\end{array}$ \\
\hline \multirow[t]{2}{*}{$\mathrm{I}(\mathrm{IDEB} \leq 3.7)$} & -1.846 & -0.791 & 3.949 \\
\hline & $(3.643)$ & $(2.684)$ & $(3.843)$ \\
\hline Mean Cont. & 21.590 & 10.225 & 17.370 \\
\hline $\mathrm{BW}$ & 0.246 & 0.248 & 0.267 \\
\hline $\mathrm{n}$ & 1618 & 1624 & 1746 \\
\hline $\mathrm{n}($ total $)$ & 7436 & 7436 & 7436 \\
\hline \multicolumn{4}{|c|}{ Panel B: School days before 6am and after 6pm } \\
\hline & $\begin{array}{l}\text { Under 18s } \\
(1)\end{array}$ & $\begin{array}{c}\text { Under } 18 \mathrm{~s} \text { - Students } \\
(2)\end{array}$ & $\begin{array}{c}\text { Above } 25 \mathrm{~s} \\
(3)\end{array}$ \\
\hline $\mathrm{I}(\mathrm{IDEB} \leq 3.7)$ & $\begin{array}{l}-3.366 \\
(3.684)\end{array}$ & $\begin{array}{l}-1.620 \\
(3.028)\end{array}$ & $\begin{array}{l}-3.423 \\
(3.904)\end{array}$ \\
\hline Mean Cont. & 25.487 & 14.417 & 19.845 \\
\hline BW & 0.312 & 0.304 & 0.239 \\
\hline $\mathrm{n}$ & 2046 & 1990 & 1544 \\
\hline $\mathrm{n}($ total $)$ & 7436 & 7436 & 7436 \\
\hline
\end{tabular}

Notes: Reduced form local linear regressions with CCT's optimal bandwidth and triangular Kernel. All regressions include year and region dummies and clustered standard errors at the school level. Mean Cont. refers to estimated coefficient at the left of the cutoff. Column one refers to individuals under 18; Column two refers to the subsample of students under 18; Column three refers to individuals above 25. Dependent variable in Panel (A) takes one if the number of drug crimes on non-school days between $6 \mathrm{am}$ and $6 \mathrm{pm}$ is greater than zero. Dependent variable in Panel (B) takes one if the number of drug crimes on school days before $6 \mathrm{am}$ and after $6 \mathrm{pm}$ is greater than zero. ${ }^{* * *} \mathrm{p}$ $<0.01,{ }^{* *} \mathrm{p}<0.05,{ }^{*} \mathrm{p}<0.1$. 
Table 4.5: Heterogeneity in student vulnerability (\% in PBF) for different types of crimes

Dep. Var.: I(Crimes $>0)$

\begin{tabular}{lcccc}
\hline Panel A: \% in PBF $>$ Median (\% in PBF) & & \\
\hline & Homicide & Vehicle & Mobile Phone & Drug \\
& $(1)$ & $(2)$ & $(3)$ & $(4)$ \\
\hline I(IDEB $\leq 3.7)$ & -3.554 & 0.571 & $-9.144^{*}$ & $-13.17^{* *}$ \\
& $(3.004)$ & $(5.64)$ & $(5.121)$ & $(5.774)$ \\
Mean Cont. & 9.704 & 55.046 & 74.974 & 64.770 \\
BW & 0.257 & 0.322 & 0.315 & 0.304 \\
$\mathrm{n}$ & 1010 & 1274 & 1252 & 1202 \\
$\mathrm{n}$ (total) & 3718 & 3718 & 3718 & 3718 \\
\hline Panel B: \% in & PBF $<$ Median(\% in PBF) & & \\
\hline \multicolumn{5}{c}{} \\
& Homicide & Vehicle & Mobile Phone & Drug \\
& $(1)$ & $(2)$ & $(3)$ & $(4)$ \\
\hline I(IDEB $\leq 3.7)$ & 2.512 & 5.505 & 2.617 & 3.478 \\
& $(5.256)$ & $(5.022)$ & $(4.526)$ & $(9.451)$ \\
Mean Cont. & 15.963 & 89.049 & 92.375 & 60.647 \\
BW & 0.409 & 0.294 & 0.282 & 0.237 \\
$\mathrm{n}$ & 1044 & 768 & 732 & 592 \\
n(total) & 3718 & 3718 & 3718 & 3718 \\
\hline
\end{tabular}

Notes: Reduced form local linear regressions with CCT's optimal bandwidth and triangular Kernel. All regressions include year and region dummies and clustered standard errors at the school level. Mean Cont. refers to estimated coefficient at the left of the cutoff. Column one refers to different classifications of homicides; Column two refers to vehicle thefts and robberies; Column three refers to mobile phone thefts and robberies; Column four refers to drug crimes. Dependent variable is the sum of crimes on school days between $6 \mathrm{am}$ and $6 \mathrm{pm}$ by a thousand students. Subsample in Panel (A) refers to schools with share of students in Bolsa Familia above the median (18.7\%). Subsample in Panel (B) refers to schools with share of students in Bolsa Familia below median (18.7\%). ${ }^{* * *} \mathrm{p}<0.01,{ }^{* *} \mathrm{p}<0.05,{ }^{*}$ $\mathrm{p}<0.1$. 
Table 4.6: Heterogeneity in student vulnerability (\% in PBF) for subsamples of drug-related crimes

Dep. Var.: I(Drug Crimes $>0$ )

\begin{tabular}{lccc}
\hline Panel A: \% in $P B F>\operatorname{Median}(\%$ in $P B F)$ \\
\hline & Under 18s & \\
& $(1)$ & $(2)$ & $(3)$ \\
\hline I(IDEB $\leq 3.7)$ & -0.164 & -7.523 & -5.657 \\
& $(5.658)$ & $(4.887)$ & $(5.442)$ \\
Mean Cont. & 34.581 & 24.023 & 27.805 \\
BW & 0.336 & 0.320 & 0.276 \\
n & 1334 & 1270 & 1082 \\
n(total) & 3718 & 3718 & 3718 \\
\hline
\end{tabular}

Panel B: \% in PBF < Median(\% in PBF)

Under 18s Under 18s - Students Above 25s

(1)

\begin{tabular}{lccc}
\hline I(IDEB $\leq 3.7)$ & -6.226 & -4.913 & 13.880 \\
& $(7.381)$ & $(7.121)$ & $(8.468)$ \\
Mean Cont. & 36.774 & 22.458 & 22.190 \\
BW & 0.302 & 0.276 & 0.264 \\
n & 784 & 718 & 692 \\
n(total) & 3718 & 3718 & 3718 \\
\hline
\end{tabular}

Notes: Reduced form local linear regressions with CCT's optimal bandwidth and triangular Kernel. All regressions include year and region dummies and clustered standard errors at the school level. Mean Cont. refers to estimated coefficient at the left of the cutoff. Column one refers to individuals under 18; Column two refers to the subsample of students under 18; Column three refers to individuals above 25 . Dependent variable takes one if the number of drug crimes on school days between $6 \mathrm{am}$ and $6 \mathrm{pm}$ is greater than zero. Subsample in Panel (A) refers to schools with share of students in Bolsa Familia above the median (18.7\%). Subsample in Panel (B) refers to schools with share of students in Bolsa Família below median (18.7\%). ${ }^{* * *} \mathrm{p}<0.01,{ }^{* *} \mathrm{p}$ $<0.05,{ }^{*} \mathrm{p}<0.1$. 


\section{5}

\section{Conclusions}

The determinants and deterrents of juvenile crime have increasingly been subject of study by economists due to its associated costs to society. Schoolbased interventions are usually proposed in order to mitigate the rise in criminal careers and the perpetuation of violence. In addition to other important crime reducing mechanisms, the existing literature has shown juveniles may be incapacitated from committing crimes while in school, although some papers have found violent crimes may increase due to extended social interactions.

This work aims to contribute to this literature by exploiting quasiexperimental variation induced by a program that extended school time in Brazil and credibly identifying the crime reducing effects of time spent in school. Accordingly, with detailed data on drug crime offenders, we show there is a lower probability of observing drug-related crimes by students around treated schools when they are in session, with no systematic difference when they are not or in non-treated groups. We also find lighter evidence of a reduced probability in thefts and robberies of mobile phones crimes. These results are consistent with an incapacitation mechanism of schools, although data limitation does not allow us to test whether violent crimes other than homicides have been affected. Importantly, heterogeneity in student vulnerability as proxied by participation on Brazil's conditional cash transfer policy shows the effects are stronger in schools with poorer students, which adds to the evidence on the incapacitation mechanism.

Additionally, unlike most previous studies, this paper tests the relevance of this channel using variation in the length of school day rather than the school calendar year or compulsory years of schooling. In particular, compared to policy prescriptions that aim at fostering incarceration on juvenile offenders, such as lowering the minimum age of criminal responsibility, it is likely that extending school time is more cost effective in reducing overall crime rates. ${ }^{1}$ Combined with the deleterious consequences juvenile incarceration has on future crime outcomes, as shown by Aizer and Doyle Jr (2015) and Bayer

\footnotetext{
${ }^{1}$ For instance, the direct monetary costs for maintaining a juvenile incarcerated in the country can be as high as 2,200 Brazilian Reais a month (around 600 US dollars). Source: Instituto Sou da Paz at http://www.danospermanentes.org/sobre.html. Accessed on April 2019.
} 
et al. (2009), alternative policy suggestions are crucial. Even though a costbenefit analysis is beyond the scope of this article, we have shown this type of school intervention may pose a relevant policy option in reducing juvenile crime, especially if targeted at more vulnerable neighborhoods. Moreover, because previous work has shown early access to illegal markets and activities is important to determine crime in adulthood, the present results give support to the role of schools in preventing overall criminal activity. 


\section{Bibliography}

Aizer, A. and Doyle Jr, J. J. (2015). Juvenile incarceration, human capital, and future crime: Evidence from randomly assigned judges. The Quarterly Journal of Economics, 130(2):759-803.

Almeida, R., Bresolin, A., Borges, B., Mendes, K., and Menezes-Filho, N. (2016). Assessing the impacts of Mais Educacao on educational outcomes: evidence between 2007 and 2011. The World Bank.

Anderson, D. M. (2014). In school and out of trouble? the minimum dropout age and juvenile crime. Review of Economics and Statistics, 96(2):318-331.

Bayer, P., Hjalmarsson, R., and Pozen, D. (2009). Building criminal capital behind bars: Peer effects in juvenile corrections. The Quarterly Journal of Economics, 124(1):105-147.

Beatton, T., Kidd, M. P., Machin, S., and Sarkar, D. (2018). Larrikin youth: Crime and queensland's earning or learning reform. Labour Economics, 52:149-159.

Becker, G. S. and Mulligan, C. B. (1997). The endogenous determination of time preference. The Quarterly Journal of Economics, 112(3):729-758.

Bell, B., Bindler, A., and Machin, S. (2018a). Crime scars: recessions and the making of career criminals. Review of Economics and Statistics, 100(3):392404.

Bell, B., Costa, R., and Machin, S. J. (2018b). Why does education reduce crime?

Berthelon, M. E. and Kruger, D. I. (2011). Risky behavior among youth: Incapacitation effects of school on adolescent motherhood and crime in chile. Journal of public economics, 95(1-2):41-53.

Billings, S. B., Deming, D. J., and Rockoff, J. (2013). School segregation, educational attainment, and crime: Evidence from the end of busing in charlottemecklenburg. The Quarterly Journal of Economics, 129(1):435-476.

Billings, S. B., Deming, D. J., and Ross, S. L. (2016). Partners in crime: Schools, neighborhoods and the formation of criminal networks. Technical report, National Bureau of Economic Research. 
Carvalho, L. S. and Soares, R. R. (2016). Living on the edge: Youth entry, career and exit in drug-selling gangs. Journal of Economic Behavior \& Organization, 121:77-98.

Cattaneo, M. D., Jansson, M., and Ma, X. (2018). Simple local polynomial density estimators. arXiv preprint arXiv:1811.11512.

Chioda, L., De Mello, J. M., and Soares, R. R. (2016). Spillovers from conditional cash transfer programs: Bolsa família and crime in urban brazil. Economics of Education Review, 54:306-320.

Cullen, J. B., Jacob, B. A., and Levitt, S. (2006). The effect of school choice on participants: Evidence from randomized lotteries. Econometrica, 74(5):11911230.

Cunha, F., Heckman, J. J., and Schennach, S. M. (2010). Estimating the technology of cognitive and noncognitive skill formation. Econometrica, 78(3):883-931.

Damm, A. P. and Dustmann, C. (2014). Does growing up in a high crime neighborhood affect youth criminal behavior? American Economic Review, 104(6):1806-32.

De Mello, J. M. and Schneider, A. (2010). Assessing são paulo's large drop in homicides: The role of demography and policy interventions. In The Economics of crime: Lessons for and from Latin America, pages 207-235. University of Chicago Press.

Deming, D. J. (2011). Better schools, less crime? The Quarterly Journal of Economics, 126(4):2063-2115.

Fernandes, G. A. A. L. (2007). O sistema de matrícula escolar de São Paulo: uma abordagem à luz da teoria dos jogos. Master's dissertation, University of São Paulo, Faculdade de Economia, Administração e Contabilidade, São Paulo.

Heller, S. B., Shah, A. K., Guryan, J., Ludwig, J., Mullainathan, S., and Pollack, H. A. (2017). Thinking, fast and slow? some field experiments to reduce crime and dropout in chicago. The Quarterly Journal of Economics, 132(1):1-54.

Jacob, B. A. and Lefgren, L. (2003). Are idle hands the devil's workshop? incapacitation, concentration, and juvenile crime. American Economic Review, 93(5):1560-1577.

Levitt, S. D. and Lochner, L. (2001). The determinants of juvenile crime. In Risky behavior among youths: An economic analysis, pages 327-374. University of Chicago Press. 
Lochner, L. (2010). Education policy and crime. In Controlling crime: strategies and tradeoffs, pages 465-515. University of Chicago Press.

Lochner, L. (2011). Nonproduction benefits of education: Crime, health, and good citizenship. In Handbook of the Economics of Education, volume 4, pages 183282. Elsevier.

Lochner, L. and Moretti, E. (2004). The effect of education on crime: Evidence from prison inmates, arrests, and self-reports. American economic review, 94(1):155-189.

Luallen, J. (2006). School's out. . forever: A study of juvenile crime, at-risk youths and teacher strikes. Journal of urban economics, 59(1):75-103.

Machin, S., Marie, O., and Vujić, S. (2011). The crime reducing effect of education. The Economic Journal, 121(552):463-484.

McCrary, J. (2008). Manipulation of the running variable in the regression discontinuity design: A density test. Journal of econometrics, 142(2):698-714.

Monteiro, J. and Rocha, R. (2017). Drug battles and school achievement: evidence from rio de janeiro's favelas. Review of Economics and Statistics, 99(2):213-228.

Oreopoulos, P. and Salvanes, K. G. (2011). Priceless: The nonpecuniary benefits of schooling. Journal of Economic perspectives, 25(1):159-84.

Sou da Paz, I. (2018). Aí voltei para o corre. Technical report, Instituto Sou da Paz.

Sviatschi, M. M. et al. (2017). Making a narco: childhood exposure to illegal labor markets and criminal life paths. Unpublished manuscript, Columbia University. 
A

\section{Additional Tables and Figures}

Table A.1: Fields of Activities in PME - São Paulo

\begin{tabular}{lcc}
\hline \hline Field & 2011 & 2012 \\
\hline Arts & 0.302 & 0.327 \\
Reinforcement Classes (Math or Portuguese) & 0.264 & 0.278 \\
Sports & 0.215 & 0.199 \\
Media and communication & 0.084 & 0.087 \\
Environmental Studies & 0.071 & 0.054 \\
Computing & 0.025 & 0.018 \\
Health Promotion and Disease Prevention & 0.016 & 0.017 \\
Human Rights Education & 0.010 & 0.008 \\
Natural Sciences Studies & 0.010 & 0.010 \\
Financial Education & 0.002 & 0.001 \\
\hline
\end{tabular}

Notes: This table shows the different fields of Mais Educação activities by descending order of popularity. Second and third columns refer to the relative share of activities picked in each one of the fields in 2011 and 2012. 
Table A.2: Reduced form results for different types of crime - intensive margin

Crimes on school days between 6am-6pm

\begin{tabular}{lcccc}
\hline \multicolumn{5}{c}{ Dep. Var.: (Crimes/Student)*1000 } \\
\hline & $\begin{array}{c}\text { Homicide } \\
(1)\end{array}$ & $\begin{array}{c}\text { Vehicle } \\
(2)\end{array}$ & $\begin{array}{c}\text { Mobile Phone } \\
(3)\end{array}$ & $\begin{array}{c}\text { Drug } \\
(4)\end{array}$ \\
\hline I(IDEB $\leq 3.7)$ & 0.000 & -0.198 & 0.050 & -0.070 \\
& $(0.004)$ & $(0.234)$ & $(0.404)$ & $(0.075)$ \\
Mean Cont. & 0.016 & 1.045 & 1.709 & 0.397 \\
BW & 0.326 & 0.260 & 0.276 & 0.245 \\
n & 2150 & 1690 & 1800 & 1612 \\
n(total) & 7436 & 7436 & 7436 & 7436 \\
\hline
\end{tabular}

Notes: Reduced form local linear regressions with CCT's optimal bandwidth and triangular Kernel. All regressions include year and region dummies and clustered standard errors at the school level. Mean Cont. refers to estimated coefficient at the left of the cutoff. Column one refers to different classifications of homicides; Column two refers to vehicle thefts and robberies; Column three refers to mobile phone thefts and robberies; Column four refers to drug crimes. Dependent variable is the sum of crimes on school days between $6 \mathrm{am}$ and $6 \mathrm{pm}$ per a thousand students. ${ }^{* * *} \mathrm{p}<0.01$, $^{* *}$ $\mathrm{p}<0.05,{ }^{*} \mathrm{p}<0.1$. 
Table A.3: Reduced form results for subsamples of drug-related crimes intensive margin

\section{Crimes on school days between 6am-6pm}

$$
\text { Dep. Var.: (Drug Crime/Student)*1000 }
$$

Under 18s Under 18s - Students Above 25s

(1)

\begin{tabular}{lccc} 
I (IDEB $\leq 3.7)$ & 0.013 & 0.002 & -0.019 \\
& $(0.025)$ & $(0.012)$ & $(0.018)$ \\
Mean Cont. & 0.107 & 0.048 & 0.082 \\
BW & 0.380 & 0.415 & 0.233 \\
n & 2470 & 2652 & 1516 \\
n(total) & 7436 & 7436 & 7436 \\
\hline
\end{tabular}

Notes: Reduced form local linear regressions with CCT's optimal bandwidth and triangular Kernel. All regressions include year and region dummies and clustered standard errors at the school level.Mean Cont. refers to estimated coefficient at the left of the cutoff. Column one refers to individuals under 18; Column two refers to the subsample of students under 18; Column three refers to individuals above 25. Dependent variable is the sum of drug crimes on school days between 6 am and $6 \mathrm{pm}$ by a thousand students. $^{* * *} \mathrm{p}<0.01,{ }^{* *} \mathrm{p}<0.05,{ }^{*} \mathrm{p}<0.1$.

Figure A.1: Artificial school districts - Examples

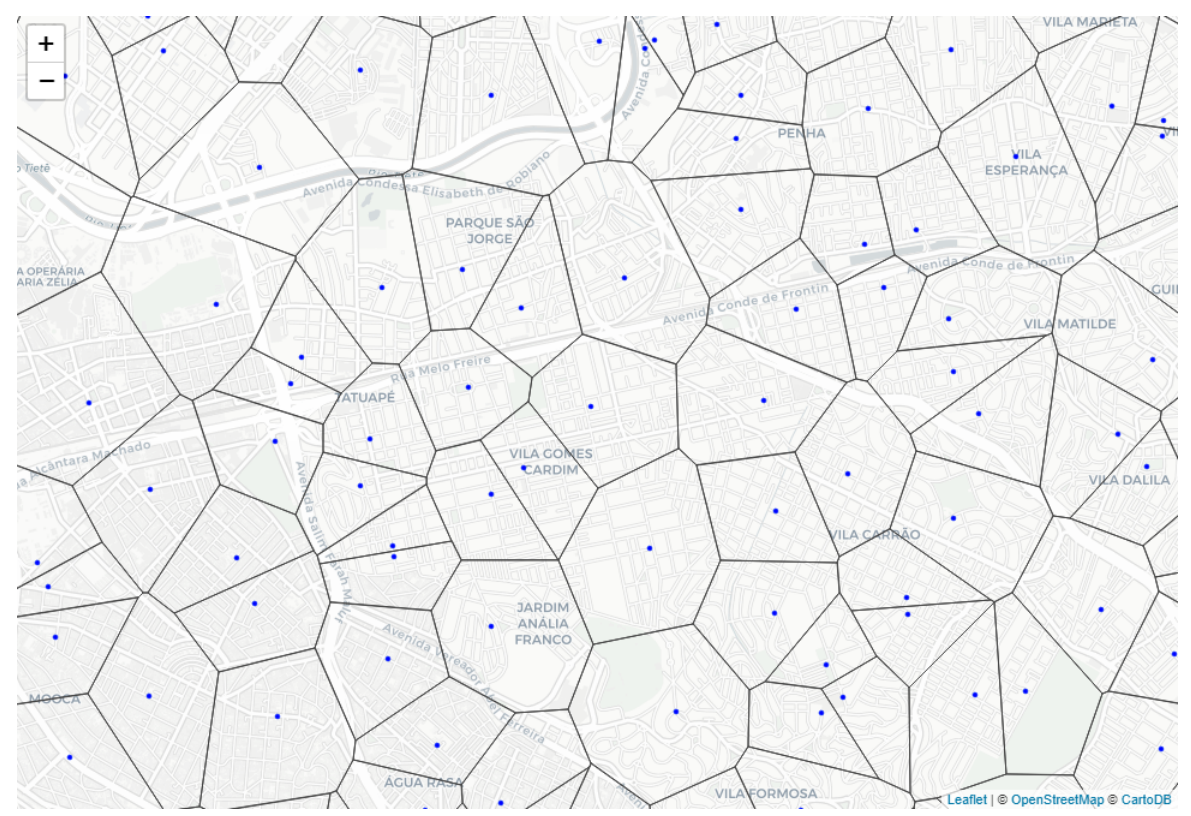

Notes: This Figure depicts artificial school districts areas around Tatuapé neighborhood in São Paulo. Each blue dot is a school and the area around it is closest to that school in comparison to every other school. Districts are bounded to a maximum 2000 meters radius to the school. 
Figure A.2: Students +6 hours - Age Distribution

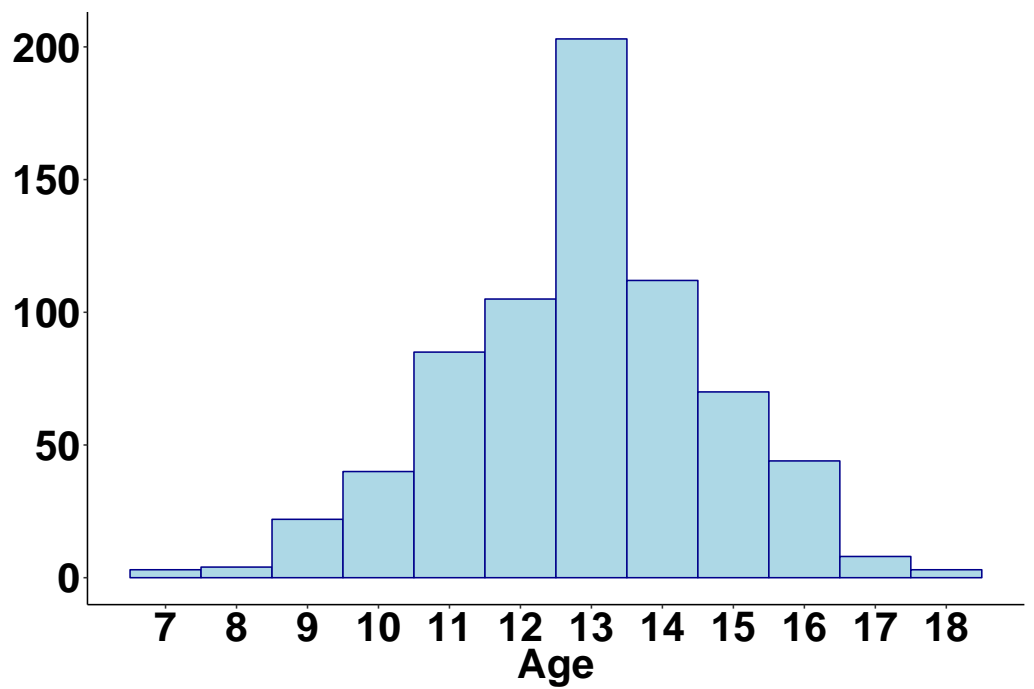

Notes: This Figure plots a histogram of students staying longer than 6 hours in Mais Educação schools in the sample by age for 2011 and 2012. Each bin counts the number of students for a certain age. The mode is 13 years old.

Figure A.3: 9th grade IDEB 2009 scores - Histogram

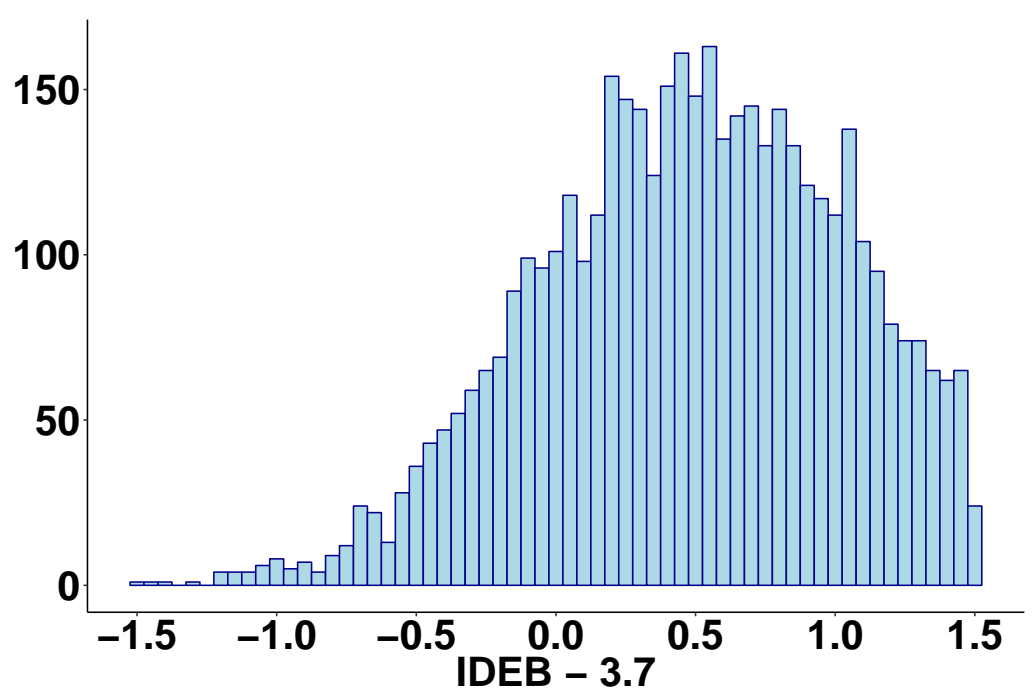

Notes: This Figure plots a histogram of schools' IDEB scores in 2009. The $\mathrm{X}$-axis variable is centered at the relevant cutoff. Each bin counts the number of schools that falls in a certain score. 